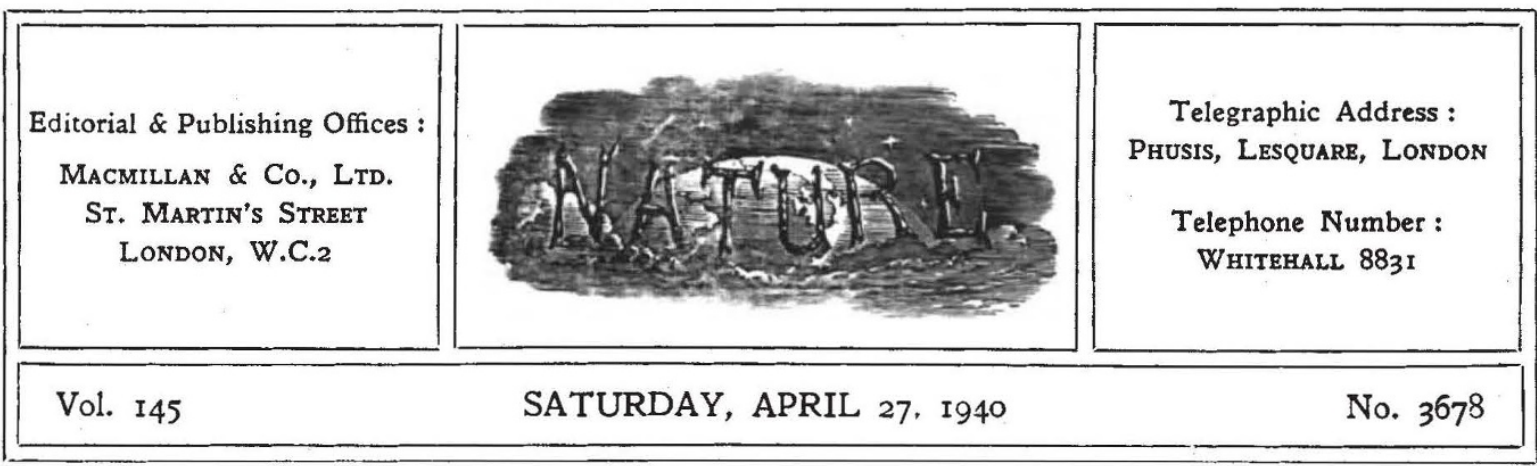

\title{
RESEARCH AND INVENTION IN UNIVERSITIES
}

$\mathrm{U}$ NIVERSITY authorities have for many years encouraged their staffs. and students to do research work, the principal reason, especially applicable to the students, probably being that research is excellent educational training and therefore falls within the sphere of the primary activity of universities. A secondary reason, especially applicable to the staffs, is that research may produce results of great public benefit and is, to that extent, not inconsistent with the reason for existence of universities.

Research is, however, costly, and university authorities are not usually provided with funds on which there are not other demands, so that it becomes necessary either to obtain additional financial surpport or to limit the research. Although all kinds of research tend to grade into one another, it can be roughly divided into two classes, 'pure' research and 'applied' research, as is indeed indicated in the title of the "Department of Scientific and Industrial Research". While the mere publication of the results of any research may be of great public benefit, the direct financial reward thus obtained either by the research worker or by the university authorities is almost negligible. 'Pure' or 'scientific' research, however, differs from 'applied' or 'industrial' research, in that while there is no ready method of obtaining a direct financial reward for the results of pure or scientific research, applied or industrial research can generally be given a direct financial reward by means of the grant of a patent. A patent is granted for "any manner of new manufacture" in Great Britain, and, by enabling the patentee to prevent anyone else from using what is patented, confers on him the power to sell the right to manufacture it to any industrial organization willing to do so. By using the patent system in this way for the results of applied or industrial research, research workers and university authorities are able to obtain direct financial support from industrial organizations additional to any financial assistance given by Government or obtained in other ways. In all the great industrial countries, research workers and university authorities use their patent systems in this way, and the financial support thus obtained provides funds for the further encouragement. of both classes of research. The methods by which different countries use their patent systems, however, have developed in different directions.

In Great Britain, university authorities have in general developed a method by which a professor is left entirely free to guide the research of his subordinate staff and the students under his care in the direction that he thinks best. He may feel that research in some particular line will give the students the best educational training or will afford the staff the best opportunity of conferring some public benefit, but in general he is left free to determine what, if any, use he will make of the patent system on the results of the research. Some professors merely publish the results made under their direction, while others take care to patent such results as seem likely to bring direct financial reward. In the former case the professor may feel that all the results of research should be freely dedicated to the public, and he may have, on this ground, an ethical objection to patenting any results. In the case of a professor who patents such results as seem likely to bring direct financial reward he may feel that by so doing he is ensuring 
that the greatest public benefit will be obtained, because, as is frequently pointed out, results of research dedicated to the public merely by publication are often most effectively withheld from the public since no one will assume the business risk and the development expense necessary to commercialize an article over which he can have no control for a reasonable period. If these results of applied or industrial research are patented, there is often an arrangement between the professor and some industrial organization giving the organization first claim on the commercial exploitation of the results in return for some financial reward and in some cases benefaction to the university.

The development in the universities in the United States of their methods of using their patent system was indicated recently by Mr. A. A. Potter, of Purdue University, in his address on "Research and Invention in Engineering Colleges" as vice-president of the Engineering Section of the American Association for the Advancement of Science. In preparing his address $\mathrm{Mr}$. Potter states that he obtained information from thirty-nine universities and colleges, of which seven had organized research foundations for administering desirable patent policies, three others had entrusted the handling of their patent matters to the Research Corporation of New York, two others had given the responsibility for patent administration to a State board, and thirteen others had formed committees or boards to deal with their patent policies. About two thirds of the universities and colleges consulted had definite patent policies and these, it is pointed out, were the universities and colleges that received the greatest support from industry. Mr. Potter reports that "those Universities and Colleges which have definite patent policies are of the opinion that both the social and economic welfare of the public are being enhanced by their methods of handling patents and of encouraging creative activity of their staff members." In his opinion there is a definite trend for universities "to set up research foundations of their own, which finance research and to which the inventor assigns all rights of his research findings. Such institutional research foundations are non-profit corporations organized for the purpose of encouraging creative talent by relieving the inventor of the financial burden and loss of time from his research interests, and by financing research from profits accruing from the sale or royalty on patents."
In Germany, the policies of the universities with regard to patents have been generally more nearly allied to those of British universities rather than to those of American universities.

The great difference between the methods of using their patent systems developed in the American universities and in British universities is remarkable, when the similarity between their ideals is borne in mind. Whatever causes have contributed to this difference and however suited to the American mind may be the policies of their universities, it is certain that the policies of British universities are more suited to the character of the British people than would be the policies of the American universities. The personal freedom and the direct responsibility which the policies of British universities in general confer on their professors are characteristics which are not found to the same extent in American universities and which we should be loath to lose.

These characteristics, although general in British universities, are not universal, for in some cases British research workers are severely discouraged from patenting the results of their research-not infrequently with unfortunate consequences to themselves and the universities. A more tolerant attitude towards the British patent system, for example, by the controlling authorities in the research by British workers on the use of ultraviolet rays in preparing anti-rachitic products of foods and medicines, would undoubtedly have resulted in much greater credit being accorded to British research workers and in thousands of pounds being received by Great Britain from all parts of the world instead of being sent from this and other countries to the United States, as has, in fact, been the case; and this is only one example of many.

It may well be that the safest course to follow in all research of which the results are likely to be of applied or industrial use is that the research worker should be free to apply for patent protection immediately he obtains his results, and should be encouraged to do so. If the results are of no commercial use little or no harm is done, but if they can be exploited commercially some industrial organization will place them on the market and so make them available to the public, the research worker will be given the credit of his results, and the beneficial owner of the patent, whether it be the research worker, the university, or others by contractual arrangement with them, will reap the financial reward. 